\title{
Bacteria-based self-healing concrete: evaluation of full scale
}

\section{demonstrator projects}

\author{
Renée M. Mors ${ }^{a, b}$, Henk M. Jonkers ${ }^{a *}$ \\ a Delft University of Technology, Faculty of Civil Engineering \& Geosciences, Department of Materials, Mechanics, Management \& Design \\ (3MD), Section of Materials and Environment, Stevinweg 1, $2628 \mathrm{CN}$ Delft, The Netherlands \\ b Green Basilisk, YES!Labs, Molengraaffsingel 10, 2629 JD Delft, The Netherlands
}

Received: 20 May 2019 / Accepted: 27 March 2020 / Published online: 08 April 2020

(C) The Author(s) 2020. This article is published with open access and licensed under a Creative Commons Attribution 4.0 International License.

\begin{abstract}
Bacteria-based self-healing concrete is an innovative concrete that contains a self-healing agent that provides the material with enhanced autonomous crack-sealing performance. A specific type of this concrete, based on a healing agent composed of bacterial spores and lactate as carbon source, has been developed and applied by the Delft University of Technology for over ten years. Under laboratory conditions it was proven that, depending on the dosage of healing agent, self-healing of cracks up to $0.8 \mathrm{~mm}$ widths occurs. As such the material potentially allows reduction of steel reinforcement used for crack width limitation in watertight constructions. Application of self-healing concrete would therefore not only result in a reduction of costs but also in improvement of environmental performance (lower $\mathrm{CO}_{2}$ footprint) and ease of in situ casting due to reduction of use of steel in waterproof applications. However, according to the EN 1990 Eurocode (Basis of structural design), customary application of a novel type of concrete must be preceded by full scale demonstrators proving evidence for safe and functional performance. In this contribution we portray full scale application of bacteria-based self-healing agent as developed by the Delft research group in two repair mortar- and in two concrete construction demonstrator projects. These demonstrator projects show that addition of the bacteria-based self-healing agent to the concrete mix is safe as no negative side effects on construction performance was observed. However, it also proved difficult to find evidence for increased crack-healing performance as cracking in the demonstrator constructions hardly occurred. In further full scale demonstrators we therefore plan to drastically reduce amount of crack width-restraining reinforcement to show crackhealing capacity and potential to save on use of reinforcement steel in watertight concrete constructions.
\end{abstract}

Keywords: Self-healing; Concrete; Bacteria; Standardization; Eurocode

\section{Introduction}

Cracking in concrete is an accepted phenomenon and does not have to lead to problems if it remains 'within limits'. These limits are laid down in codes describing what are acceptable crack widths for concrete structures in specific environments. E.g. Eurocode EN 1992-1-1 Design of concrete structures' recommends maximum crack widths of $0.4 \mathrm{~mm}$ for concrete structures exposed to environments classified as XO (no risk of corrosion or attack) and XC1 (risk of corrosion induced by carbonation for dry or permanently wet constructions) and $0.2 \mathrm{~mm}$ for more aggressive environments (XC2-4: corrosion induced by carbonation; XD1-3: corrosion induced by chlorides and XS1-3: corrosion induced by chlorides from seawater) [1]. Depending on the concrete mix composition and the amount of reinforcement applied, the construction can be designed in such a way that crack formation can remain limited. Nevertheless, we see in practice that crack formation can lead to unforeseen leakage problems or premature corrosion of the reinforcement resulting in the need for intervention. This often leads to unforeseen and high repair costs during or after finalization of the construction. The difference between anticipated (theoretical) crack formation and practical occurrence is caused by a number of factors which are often beyond the control of the designer. A strategy, in addition to the currently widely applied options such as inclusion of waterproof membranes, application of more crack-width-restricting reinforcement or manual injection repair of cracks afterwards, is to 'manage' the risk of unforeseen crack occurrence by applying a concrete with a high crack-sealing capacity: self-healing concrete [2]. In this paper the application and performance of a specific bacteriabased healing agent developed by the Delft University of Technology research group in full scale demonstrator projects targeting both prefabricated and in-situ cast constructions and a specifically developed repair mortar is evaluated.

\footnotetext{
* Corresponding author: Henk M. Jonkers, Email: H.M.Jonkers@tudelft.n
} 


\section{Autogenous healing of concrete}

Every type of concrete comprises a certain crack-sealing capacity. Documented research has shown that the capacity of this so-called 'autogenous' crack-healing relates particularly to the Portland clinker content and the particle size of the cement. The higher the dosage and the coarser the cement, the higher the autogenous crack-sealing capacity of the concrete [3-5]. However, high clinker content and course particle size of cement oppose technical developments of the last decades typically favouring a low clinker content for lowering the $\mathrm{CO}_{2}$ footprint and high Blaine values of cement for obtaining rapid strength development. However, such low clinker cements, usually high in slag and / or fly ash content, typically show a decreased autogenous crack-healing capacity [6]. It can therefore be questioned whether low clinker blended cement systems still show sufficient autogenous crack-healing potential to ensure water tightness as is assumed for traditional CEMI-dominated binder systems [3]. However, returning to high clinker cements appears from an environmental viewpoint undesirable but on the other hand (relatively) low clinker containing concretes should also comprise a sufficient degree of crack-healing capacity to ensure water tightness of water exposed constructions. Challenge therefore is to achieve additional autonomous crack repair capacity while simultaneously decreasing the $\mathrm{CO}_{2}$ impact of the concrete.

\section{Autonomous crack repair by limestone- forming bacteria}

Of the large number of bacterial species that occur in nature, there are only a limited number that survive 'casting' in concrete. These specific bacteria are not only adapted to the high alkaline conditions of concrete but also form spores. These spores are resistant to most forms of stress such as high pressure, aggressive chemicals, high temperatures and dehydration $[2,13]$. The spores germinate when suitable nutrients and water become available transforming them from metabolically inactive to active (vegetative) bacteria. The active bacteria can produce limestone as a metabolic byproduct, specifically in alkaline and calcium ion-rich environments such as occurring in the concrete matrix (Fig. 1).
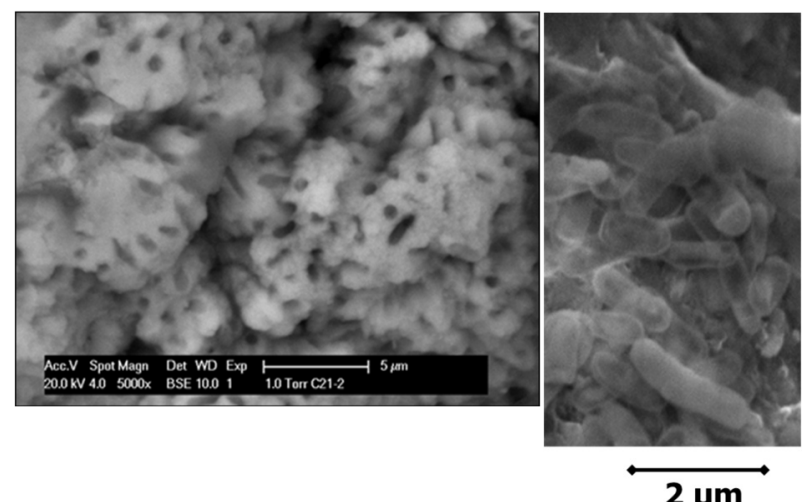

Figure 1. Environmental Scanning Electron Microscopic image of bacterial limestone (evidenced by bacterial imprints; left image) and light microscopic image of active (vegetative) alkali-resistant bacteria of the genus Bacillus (right image). Courtesy Arjan Thijssen, TU Delft.
Limestone, or calcium carbonate, is a concrete compatible material that is perfectly suitable for sealing (waterproofing) of cracks in concrete. Several research groups worldwide have developed bacteria-based healing agents to enhance the self-healing capacity of cement pasts, mortars and concrete [7-12]. Pioneering and lab-based research by the Delft research group has shown that lactate-based organic compounds like calcium lactate and lactide-polymers) are suitable carbon sources for the bacteria and that these compounds are furthermore concrete compatible in the sense that they as additive, within limits, do not negatively

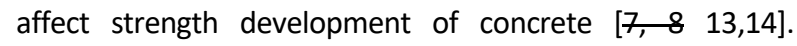
Moreover, lactate is allowed as concrete additive according to the European norm on admixtures [15]. Published lab-based studies have shown that, depending on the dosage of bacteria and lactate-based nutrients, cracks of up to $0.8 \mathrm{~mm}$ width can be sealed autonomously $[14,16]$. Healing of $0.8 \mathrm{~mm}$ wide cracks requires a dosage of $15 \mathrm{~kg}$ of $B$. alkalinitrilicuscomprising self-healing agent per $\mathrm{m}^{3}$ of concrete mix , while a dosage of $5 \mathrm{~kg} / \mathrm{m}^{3}$ leads to the autonomous waterproofing of $0.4 \mathrm{~mm}$ wide cracks (Figure 2) [17]. The composition of the healing agent used was $0.1 \%(\mathrm{w} / \mathrm{w})$ dried $B$. alkalinitrilicus spores and $2 \%$ Yeast $(\mathrm{w} / \mathrm{w})$ extract both embedded in a lactate-based polymer matrix $(97,7 \% \mathrm{w} / \mathrm{w})$, latter functioning both as nutrient source and protective coating for the bacterial spores [21] and is commercially produced and marketed by Green-Basilisk B.V., The Netherlands.

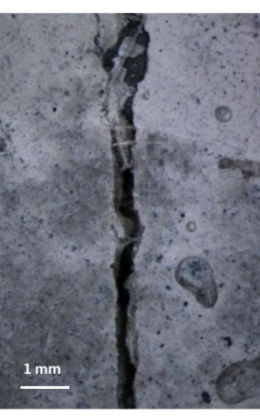

$\mathbf{t}=\mathbf{0}$

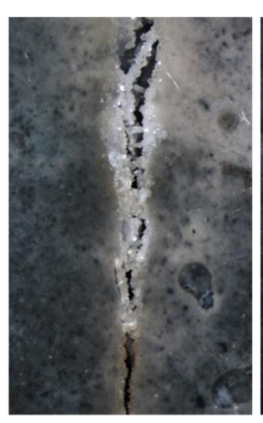

$\mathbf{t}=\mathbf{2 4 d}$

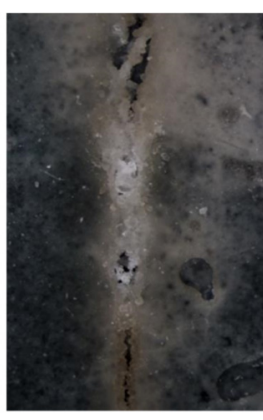

$\mathbf{t}=\mathbf{5 8 d}$
Figure 2. Self-healing of an $0.8-\mathrm{mm}$ wide crack in concrete at a dosage of $15 \mathrm{~kg}$ of self-healing agent per $\mathrm{m}^{3}$ takes up to two months [17].

\section{Development of bacteria-based self-healing agent}

The functional components of the bacteria-based self-healing agent as developed by the Delft research group consist of bacterial spores and nutrients. The bacterial spores resist and survive incorporation in concrete while the nutrients are required for spore germination (conversion of metabolically inactive spores into active vegetative cells) and as precursor material for the limestone to be produced [13]. In initial studies the nutrients consisted of yeast extract for germination of spores and calcium lactate as limestone precursor compound and these two components were together with bacterial spores loaded into expanded claybased porous aggregates (Fig. 3) [16]. Latter aggregates thus served as carrier material for the active healing agent components. Advantage of use of a porous carrier is that it 
forms, in comparison to regular aggregates, weak spots in the concrete matrix which attract forming cracks. The cracks that hit and split porous aggregate particles thus ensure effective release of embedded active healing agent compounds into the crack $[18,19]$. Disadvantage of use of porous carrier aggregates is that they significantly lower the compressive strength of the concrete $[16,20]$. A next generation selfhealing agent was therefore developed by the Delft group and in this one the active healing agent components (bacterial spores, yeast extract and lactate-derivatives) were pelleted using combined powder compression- and extrusion techniques which made the use of expanded clay carriers redundant [14]. Major advantage of the new generation healing agent is that it consists of $100 \%$ bio-based active ingredients not resulting in decrease of compressive strength of the resulting concrete if dosed correctly [21]. Activator of the healing agent is crack-ingress water what initiates germination of the bacterial spores. Metabolically active cells subsequently convert the lactate-derivatives into calcium carbonate-based insoluble minerals which, when sufficiently formed, block and waterproof cracks. Application fields of the bacteria-based healing agent are therefore limited to concretes exposed to moist conditions as water is required for the activation of the system as was established in documented studies [16, 17. 21-23]. Activation (germination) of the applied alkaliphilic bacterial spores occurs in $\mathrm{pH}$ range from 8 to 11.5 [2]. As the $\mathrm{pH}$ of the concrete mix during preparation and casting is well above 11.5 , activation of the spores does not occur at this stage but only when $\mathrm{pH}$ drops below 11.5 due to external water that ingress cracks [24].

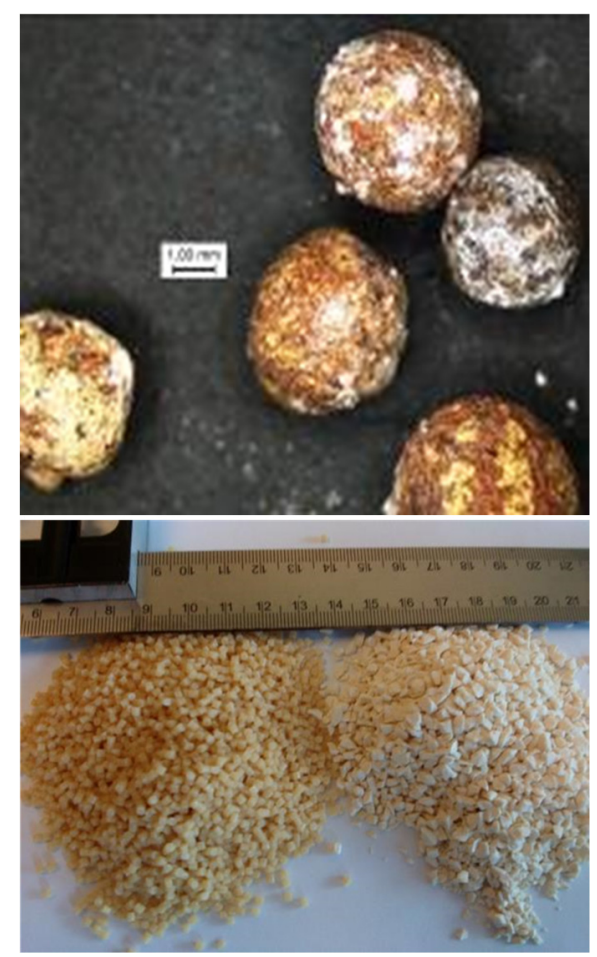

Figure 3. First generation expanded clay based healing agent (top image) and next generation lactate-derivative based healing agent (bottom image).

\section{Application potential bacteria-based self- healing agent}

\subsection{Self-healing repair mortar}

First full scale application of the bacteria-based self-healing agent as developed by the Delft research group was in form of a self-healing repair mortar (see paragraph 6.1 below). This healing agent- and PVA fibre-based mortar, developed by Sierra-Beltran et al., is characterized by a low modulus of elasticity and additional strain-hardening behaviour [25, 26]. This latter property results during deformation in appearance of repetitive small sized cracks $(<0.1 \mathrm{~mm}$ wide) allowing substantial deformation without instant brittle material failure. The strain hardening behaviour is due to the presence ( $1-2 \%$ by volume) of small ( $8 \mathrm{~mm}$ long and $0.04 \mathrm{~mm}$ diameter) but strong polyvinyl alcohol (PVA) fibres which tensile strength is order of magnitude higher than that of the mortar matrix. The tensile deformation capacity of this PLA fibrebased mortar is 3 to $5 \%$ which is substantially higher than the typical $0.3 \%$ for traditional non-fibre based repair mortars. Applying PVA fibres in combination with the bacteria-based self-healing agent ensures quick autonomous healing of cracks formed under tensile- or flexural loading and high bond strength between repair mortar and underlying concrete. Typical composition of the strain-hardening bacteria-based self-healing repair mortar per $\mathrm{m}^{3}$ is: $449 \mathrm{~kg}$ CEMI $42,5 \mathrm{~N} ; 538$ kg Fly ash; $260 \mathrm{~kg}$ limestone powder; $120 \mathrm{~kg} \mathrm{0-2} \mathrm{mm}$ aggregate; $10 \mathrm{~kg}$ next generation bacteria-based healing agent; $390 \mathrm{~kg}$ water; $20 \mathrm{~kg}$ superplasticizer (Cugla Cretoplast SL01) and $22 \mathrm{~kg}$ PVA fibres (Kuraray, Japan) [25].

\subsection{Self-healing concrete}

Constructions in wet environments can specifically benefit from self-healing of cracks $[27,28]$. Watertight constructions are commonly designed in such a way that only cracks of smaller than $0.1 \mathrm{~mm}$ width are allowed to occur as these are expected to self-heal due to autogenous healing capacity of the concrete [3]. Such designs, however, require a lot of crack width restraining reinforcement in addition to structural reinforcement steel. Disadvantage of applying abundant steel is nevertheless threefold: expensive, featuring high $\mathrm{CO}_{2}$ footprint, and finely meshed network hampers easy casting of the concrete mix (Fig. 4). Instead, designing watertight constructions for marine- and freshwater applications, allowing crack widths of $>0.1$ up to $0.4 \mathrm{~mm}$ would save crack restraining steel. This will result not only in more economic structures but additionally also to lower $\mathrm{CO}_{2}$ footprint structures with increased ease of placement of the concrete mix. Latter will allow to work faster and will also lower the risk of forming gravel nests and hollow spaces in the structure. Water tightness of these structures will be delivered by autonomous crack-sealing of mixtures requiring a dosage of 5 to $8 \mathrm{~kg} / \mathrm{m}^{3}$ healing agent. 


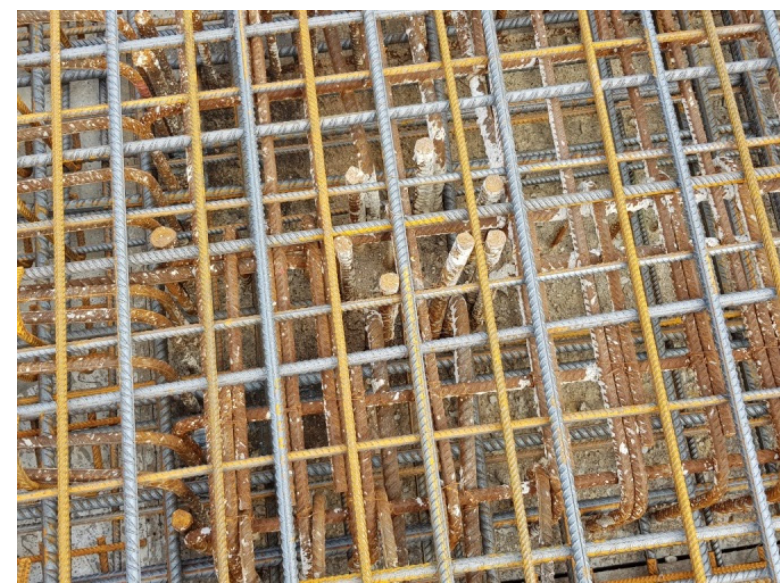

Figure 4. Picture of a finely meshed reinforcement network for watertight concrete constructions impeding easy casting of concrete.

\section{Full scale demonstrator projects}

\subsection{Self-healing repair mortar}

The developed bacteria-based self-healing repair mortar developed by the Delft research group was applied in two full scale projects in order to demonstrate practical applicability and functional performance. Projects were selected to demonstrate structural repair applicability and delivery of water tightness of cracked concrete basement walls respectively. In the first project the concrete cover of damaged steel reinforced concrete columns were replaced. Therefore, on site at the chemical plant 'Chemelot', located in Limburg, The Netherlands, the damaged cover zone up to 4 $\mathrm{cm}$ depth behind the embedded rebars was removed and replaced with bacteria-based self-healing repair mortar (Fig. 5). The repair mortar was classified as structural repair mortar R3, suitable for structural repair of concrete with a required compressive strength of up to $45 \mathrm{MPa}$.

The second project involved repair of cracked and actively leaking parking garage basement walls located 20 meter below ground level of the 'Groningen Forum' building, located in Groningen, The Netherlands. Before application of the bacteria-based self-healing repair mortar, present actively water-leaking cracks were cut open to a depth of $5 \mathrm{~cm}$ to provide sufficient bond surface for the to be applied repair mortar. Water flow was temporarily stopped through application of a 5-mm thick layer of fast setting cement, immediately followed by manual application of the repair mortar by filling up the crack cavities to level concrete surface (Fig. 6).

\subsubsection{In situ monitoring techniques for self- healing repair mortar}

In situ constructions should preferably be tested for functional performance in a non-destructive way in order not to decrease structural- and aesthetic performance [29]. Therefore three non-destructive techniques were used for determining functional performance of applied self-healing repair mortar in the two demonstrator projects described above in section 6.1 .

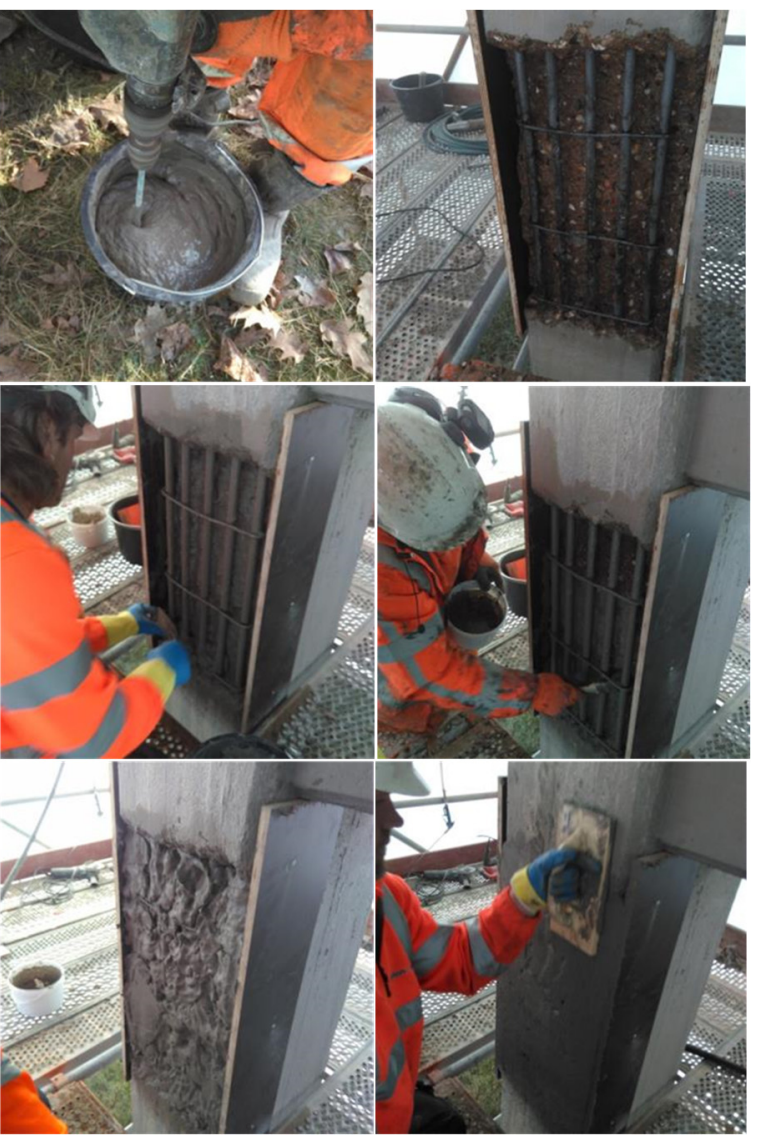

Figure 5. On site structural repair of damaged steel reinforced concrete column with bacteria-based self-healing repair mortar.

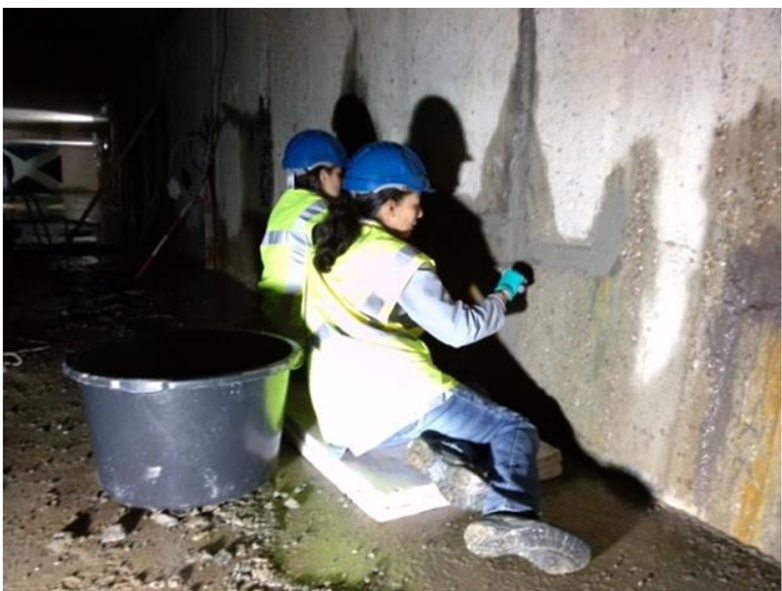

Figure 6. Manual repair of actively leaking cracked concrete basement walls using bacteria-based self-healing repair mortar.

The two qualitative techniques applied comprised visual determination of water tightness of repaired and previously leaky spots, and hammer-knocking testing for acoustic establishment of proper bonding of the applied repair mortar to the underlying concrete. Quantitative determination of mortar porosity was done by application of the Karsten-Tube water absorption test (TQCSHEEN, Netherlands) on dry mortar surface areas. Latter test involves quantitative establishment of water uptake over time of a selected surface area [30]. The three non-destructive testing techniques were employed for comparison both on the applied repair mortar 
patches and the immediately surrounding original concrete surface areas. Bi-yearly monitoring during two subsequent years of both demonstrator projects showed that repaired patches remained watertight, showed sound bonding to the underlying concrete, and revealed no decrease in porosity over time and difference in comparison to the surrounding original and sound concrete.

\subsection{Self-healing concrete}

By the Delft research group two full scale demonstrator projects with bacteria-based self-healing concrete were executed. The first one concerned construction of a wastewater purification tank consisting of precast concrete elements. This project was carried out in collaboration with the Water Boards authority Limburg (WBL), the Netherlands. The WBL's question was whether the application of selfhealing concrete could lead to a reduction in cost-ofownership, i.e. costs that are incurred over the entire life cycle of a construction. In particular, maintenance and repair costs of traditional concrete structures are high (typically $50 \%$ of WBL budget is spent on maintenance of current assets and $50 \%$ on building new constructions) and the use of selfhealing concrete can potentially result in costs saving due to reduced need for repair in combination with an increased life time of the construction. Therefore it was decided to carry out a demonstrator project in the form of a wastewater treatment tank. The tank, consisting of prefab elements with dimensions of $7.00 \times 2.50 \times 0.15 \mathrm{~m}$ produced by company BestCon, Best, The Netherlands, was installed in March 2016 at a test site in Simpelveld, The Netherlands, and put into operation in August 2016 (see Fig. 7, tank under construction and tank in operation). Three out of the 15 applied prefab elements were cast with a dosage of $10 \mathrm{~kg}$ healing agent per $\mathrm{m}^{3}$ concrete mix while the other 12 served as reference elements. To date (September 2019), after being more than 3 years in operation no sign of cracking or other forms of degradation or damage in both self-healing and reference type of elements has been observed. Therefore, although already fully functional for a 3-years period, as yet no conclusion can be drawn on possible benefits of using selfhealing concrete in for this specific application. At best it can be concluded that so far no negative effects of the healing agent additive have been observed. Ongoing monitoring of element performance in the coming years will show if application of self-healing technology for this type of application will proof to be cost effective with respect to maintenance requirements and service life performance.

The second full scale self-healing concrete demonstrator project involved an in situ cast rectangular concrete water reservoir. The tank, located in Hoogvliet, The Netherlands, was built in October 2017 by contractor BAM and commissioned by the Port of Rotterdam harbour authority and serves as fire extinguishing water reservoir. The reservoir is a rectangular concrete tank of 47 meters long, 5 meters high and 5.5 meters wide (Fig. 8). To enable determination of functional performance of self-healing concrete in comparison to traditional concrete, only half of the tank's concrete was amended with self-healing agent at a dosage of $5 \mathrm{~kg} / \mathrm{m}^{3}$. Therefore two walls of the tank (South and
East facing) were made of self-healing concrete and the other two (North and West facing) of traditional concrete (same mix design without self-healing agent). The amount of applied steel reinforcement was equal in self-healing and reference concrete and was in accordance with design criteria to allow only occurrence of cracks with a maximum width of $0.1 \mathrm{~mm}$. Because of strict water tightness constraints demanded by the owner, self-healing technology was used in this case as an additional precautionary measure to ensure water tightness of particularly the South facing wall (experiencing highest temperature fluctuations over time). The tank was filled with water in the summer of the year 2018, and during filling only minor non-leaking hairline cracks were observed in the North facing wall (not containing healing agent) but not in the other walls. To date, after being more than one year in full service, no actively leaking cracks have been observed in all walls. As such this demonstrator project has as yet not been successful as the aim was to compare crack-sealing efficiency of selfhealing- versus traditional concrete walls. Like the first prefabricated wastewater treatment tank demonstrator project, also this in situ cast concrete reservoir will be monitored in the coming years to establish long-term water tightness and service life performance.

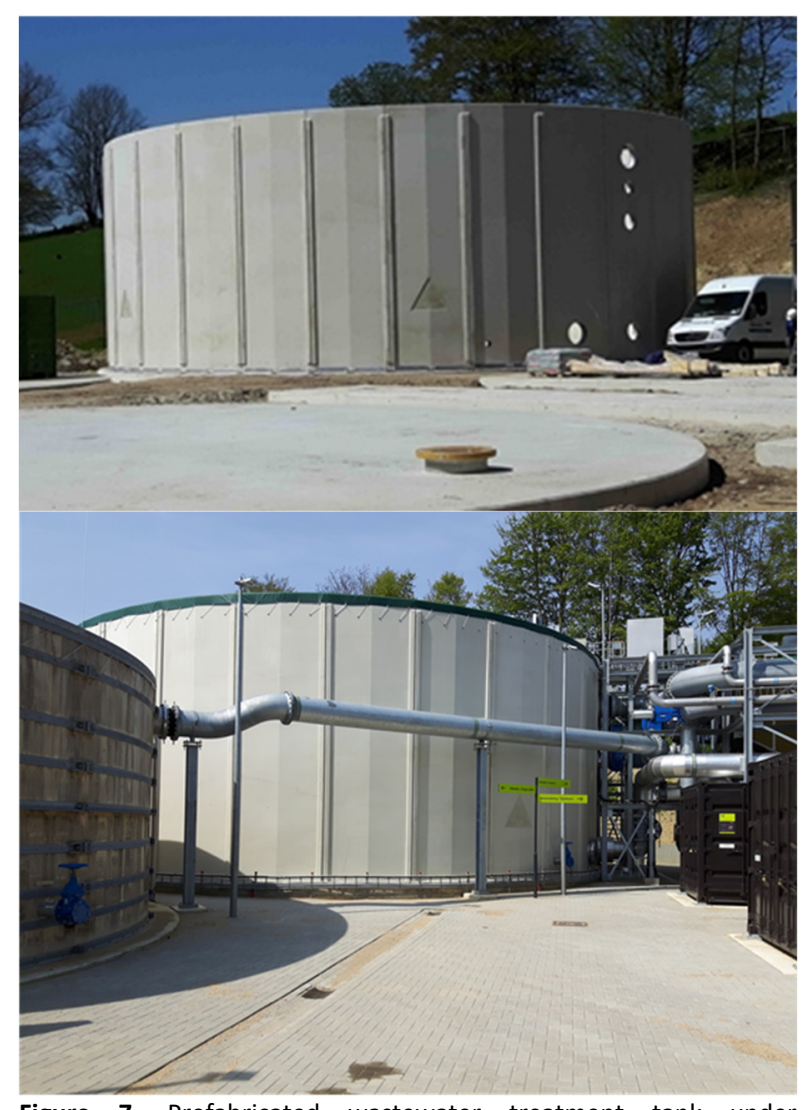

Figure 7. Prefabricated wastewater treatment tank under construction (top image) and in service (bottom image). Prefab elements bearing the triangular logo contain self-healing agent while the other, reference elements, do not. 


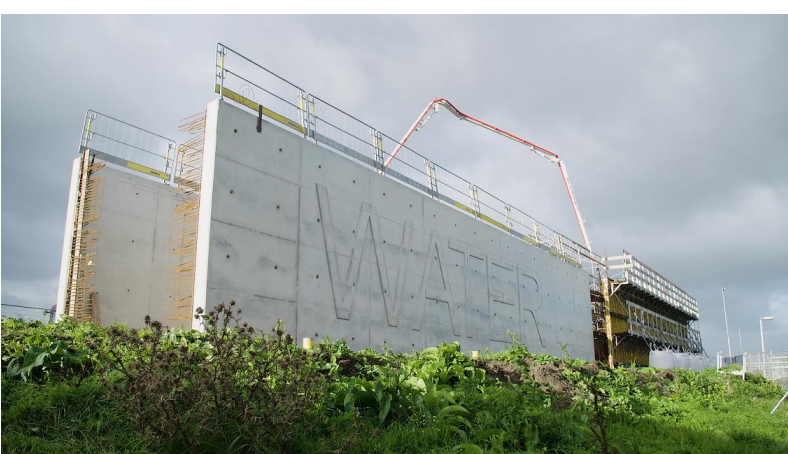

Figure 8. Full scale demonstrator In situ cast self-healing concrete water reservoir, Hoogvliet, The Netherlands.

\subsubsection{In situ monitoring techniques for self- healing concrete}

Functional performance of the applied self-healing concrete in both demonstrator projects was monitored during biyearly inspections. Visual inspections were done for establishment of crack occurrence and water permeability of the concrete cover (surface) layer was quantified by applying the Karsten Tube water absorption test (see section 6.1.1 above). During the three years monitoring period for the prefab water treatment tank and one year period for the in situ cast tank no crack occurrence or difference in water permeability between self-healing concrete and reference concrete was observed in either of the two demonstrator structures. Crack occurrence, however, was a prerequisite for enabling establishment of self-healing performance. Both the prefab elements for the wastewater purification tank and the in situ cast concrete for the fire extinguishing water tank were reinforced with steel rebars in accordance to current standards. The amount of crack width restraining steel reinforcement and execution of both projects was apparently of such a sound quantity and quality that crack formation resulting in water leakage did not occur. In hindsight it can therefore be concluded that additional autonomous selfhealing was not required in both type of constructions. Based on these results a new demonstrator project is currently planned in which the amount of crack width restraining reinforcement will be drastically reduced, i.e. targeting a maximal crack width of up to $0.4 \mathrm{~mm}$ instead of $<0.1 \mathrm{~mm}$ for watertight constructions. The applied amount of self-healing agent in this newly planned demonstrator project should not only ensure water tightness through self-sealing behaviour of occurring cracks but also result in both environmental and economic profit through reduction of steel reinforcement.

\section{Discussion and conclusions}

In the last two decades many studies targeting the development of concrete with enhanced self-healing properties appeared in literature which are mostly covered by recent review papers [7-12, 22-23, 28-29]. Although several mechanisms for enhancing the autogenous self-healing capacity of concrete have been investigated under lab conditions only few have been up scaled and applied on demonstrator scale in field trials. Besides the demonstrator projects executed by the Delft research group, as described in this paper, also UK-based research groups participating in the
Materials for Life (M4L) research program recently reported on a larger scale outdoors demonstrator project [27, 31-32]. In that large-scale field trial four different self-healing mechanisms were tested in concrete retaining wall panels of dimensions $1.8 \times 1 \times 0.15 \mathrm{~m}$ [27]. The four self-healing agents and mechanisms investigated comprised sodium silicateloaded microcapsules, bacteria-loaded porous aggregates, shape memory polymers and mineral healing agent delivering vascular flow networks [30]. Monitoring of self-healing performance of the via mechanical loading pre-cracked panels comprising the four incorporated self-healing techniques was done by following crack width- and permeability decrease in time. Crack width variations were monitored by ultrasonic pulse velocimetry and optically by camera and microscopy, and permeability quantified by quantification of in situ air permeability [31]. Intermediate results indicate that particularly the sodium silicate-loaded microcapsule based panel show significant crack-width reduction and recovery of permeability [27]. Final results and conclusions on performance of also the other three investigated healing techniques is still pending and currently being monitored under the M4L follow up program 'Resilient Materials for Life (RM4L) program [27, 31].

Cracks 'management' instead of crack prevention

Waterproof concrete structures should not crack or occurring cracks should generally be smaller than $0.1 \mathrm{~mm}$ wide to minimize amount of water leakage. Such designs require use of sufficient steel rebars in order to restrain occurring cracks to the required maxim width. The smaller the intended crack formation, the more crack width limiting reinforcement must be applied. This strategy, aiming for prevention of crack occurrence, thus requires a substantial amount of reinforcement. As a result, the placement of in situ concrete will require extra attention in order to get the concrete mixture evenly distributed through the fine reinforcement meshes of the reinforcement to avoid risk of obtaining implementation-related defects. Alternatively a waterproof membrane system should be installed or cracks should be repaired afterwards by manual waterproofing injection techniques. However, enhanced autonomous self-healing of cracks now also represents an alternative strategy, i.e. 'management' of cracks instead of preventing their occurrence. A watertight construction design based on implementation of additional autonomous self-healing could therefore represent an alternative to application of abundant crack width restraining steel reinforcement. The concept of crack management will not only save material and reduce costs but also significantly lower the environmental footprint $\left(\mathrm{CO}_{2}\right.$ impact) of steel reinforced concrete structures. Moreover, reduction of crack width restraining steel may also be beneficial during the construction process because a coarser reinforcement network lowers the risk of occurrence of execution related problems. Self-healing of up to $0.4 \mathrm{~mm}$ wide cracks should also ensure a waterproof construction, in line with the 'crack management' instead of 'crack prevention' design concept. In the two full scale selfhealing concrete demonstrators described above, self-healing technology was applied as extra safety measure to guarantee 
water tightness. While no negative effects of addition of selfhealing agent to the concrete mix and application was observed, the full capacity of the technology in relation to reinforcement reduction potential still needs to be resolved in future full scale demonstrator projects. These new demonstrators will, if successful, help to launch concrete selfhealing technology as a serious crack management alternative to the current crack prevention design strategies.

\section{Acknowledgements}

Financial support for this work from Agentschap NL (grant IOP-SHM01018) and BE Basic (grant F04.001) is gratefully acknowledged.

\section{References}

[1] Eurocode EN 1992-1-1 (2004): Eurocode 2: Design of concrete structures - Part 1-1: General rules and rules for buildings [Authority: The European Union Per Regulation 305/2011, Directive 98/34/EC, Directive 2004/18/EC

[2] H.M. Jonkers, Self-healing concrete: a biological approach., In: S. van der Zwaag (Ed.), Self Healing Materials: an introduction. Springer, The Netherlands, 195-204.

https://doi.org/10.1007/978-1-4020-6250-6 9

[3] C. Edvardsen, Water permeability and autogenous healing of cracks in concrete - ACI Materials Journal (1999) 6 (4): 448-454.

[4] AM. Neville, Autogenous healing - A concrete miracle? Concrete Int (2002) 24 (11): 76-82.

[5] N. Ter Heide, E. Schlangen, K. van Breugel, Experimental Study of Crack Healing of Early Age Cracks. Proc. Knud Højgaard Conference on Advanced Cement-Based Materials, Technical University of Denmark, June 2005.

[6] D. Palin, VAC. Wiktor, HM. Jonkers, Autogenous healing of marine exposed concrete: Characterization and quantification through visual crack closure. Cem Concr Res (2015) 73: 17-24.

https://doi.org/10.1016/i.cemconres.2015.02.021

[7] YS. Lee, W. Park, Current challenges and future directions for bacterial self-healing concrete. Appl Microbiol Biotechnol (2018) 102: 3059-3070. https://doi.org/10.1007/s00253-018-8830-y

[8] N. De Belie, Application of bacteria in concrete: a critical review. RILEM Tech Lett (2016) 1: 56-61. https://doi.org/10.21809/rilemtechlett.2016.14

[9] K. Vijay, M. Murmu, SV. Deo, Bacteria based self healing concrete - a review. Constr Build Mater (2017) 152: 1008-1014. https://doi.org/10.1016/i.conbuildmat.2017.07.040

[10] G. Souradeep, P. Sze Dai, K. Harn Wei, Autonomous healing in concrete by bio-based healing agents - a review. Constr Build Mater (2017) 146: 419-428. https://doi.org/10.1016/i.conbuildmat.2017.04.111

[11] Y. Al-Salloum, S. Hadi, H. Abbas, T. Almusallam, MA. Moslem, Bioinduction and bioremediation of cementitious composites using microbial mineral precipitation - a review. Constr Build Mater (2017) 154: 857-876.

https://doi.org/10.1016/j.conbuildmat.2017.07.203

[12] S. Joshi, S. Goyal, A. Mukherjee, M. Sudhakara Reddy, Microbial healing of cracks in concrete: a review. J Ind Microbiol Biotechnol (2017) 44: 1511-1525. https://doi.org/10.1007/s10295-017-1978-0

[13] H.M. Jonkers, A. Thijssen, G. Muyzer, O. Copuroglu, E. Schlangen, Application of bacteria as self-healing agent for the development of sustainable concrete. Ecol Eng (2010) 36 (2): 230-235. https://doi.org/10.1016/i.ecoleng.2008.12.036

[14] R.M. Mors, H.M. Jonkers, Feasibility of lactate derivative based agent as additive for concrete for regain of crack water tightness by bacterial metabolism. Ind Crops Prod (2017) 106: 97-104. https://doi.org/10.1016/i.indcrop.2016.10.037

[15] EN 934-6:2019 Admixtures for concrete, mortar and grout. Sampling, assessment and verification of the constancy of performance.

[16] V. Wiktor, HM. Jonkers, Quantification of crack-healing in novel bacteria-based self-healing concrete. Cem Concr Compos (2011) 33: 763-770. https://doi.org/10.1016/i.cemconcomp.2011.03.012

[17] R. Mors, H. Jonkers, B van der Woerd. Automatic repair of concrete in wet environment by inbuilt bacteria. Concrete, Journal of the Concrete Society, United Kingdom, Volume 51, July 2017. https://doi.org/10.3390/coatings7040051
[18] S.V. Zemskov, H.M. Jonkers, F.J. Vermolen, An analytical model for the probability characteristics of a crack hitting an encapsulated selfhealing agent in concrete. CASC, LNCS 6244, Gerdt et al. (Eds.), Springer-Verlag Berlin Heidelberg 2010, 280-292. https://doi.org/10.1007/978-3-642-15274-0 25

[19] SV. Zemskov, HM. Jonkers, FJ Vermolen, Two analytical models for the probability characteristics of a crack hitting encapsulated particles: Application to self-healing materials. Comput Mater Sci (2011) 20: 3323-3333. https://doi.org/10.1016/j.commatsci.2011.06.024

[20] H.M. Jonkers, Bacteria-based self-healing concrete. Heron (2011) 56: 1-12.

[21] R.M. Mors, H.M. Jonkers, Effect on concrete surface water absorption upon addition of lactate derived agent. Coatings (2017) 7 (4): 1-10. https://doi.org/10.3390/coatings7040051

[22] H. Amer Ali Algaifi, S. Abu Bakar, AR. Mohd Sam, AR. Zainal Abidin, Crack-healing in cementitious material to improve the durability of structures: review. MATEC Web of Conferences (2018) 250: 1-12 https://doi.org/10.1051/matecconf/201825003005

[23] N. De Belie, et al., A review of self-healing concrete for damage management of structures. Adv Mater Interfaces (2018) 1-28. https://doi.org/10.1002/admi.201800074

[24] SD. Nielsen, K. Koren, K. Lobmann, M. Hinge, A. Scoma, KU. Kjeldsen $\mathrm{H}$. Roy, Constraints on $\mathrm{CaCO} 3$ precipitation in superabsorbent polymer by aerobic bacteria. Appl Microbiol Biotechnol (2020) 104 (1): 365-375. https://doi.org/10.1007/s00253-019-10215-4

[25] M.G. Sierra-Beltran, H.M. Jonkers, E. Schlangen, Characterization of sustainable bio-based mortar for concrete repair. Constr Build Mater (2014) 67: 344-352. https://doi.org/10.1016/j.conbuildmat.2014.01.012

[26] MG. Sierra-Beltran, HM. Jonkers, Crack self-healing technology based on bacteria. J Ceram Process Res (2015) 16 (1): 1-7.

[27] A. Al-Tabbaa, C. Litina, P. Giannaros, A. Kanellopoulos, L. Souza, First UK field application and performance of microcapsule-based selfhealing concrete. Construction and Building Materials (2019) 208: 669-685. https://doi.org/10.1016/j.conbuildmat.2019.02.178

[28] N-X. Hang, F. Xing, A comprehensive review of the study and development of microcapsule based self-resilience systems for concrete structures at the Shenzhen University. Mater (2017) 10(2):125. https://doi.org/10.3390/ma10010002

[29] M. Sanchez, P. Faria, L. Ferrara, E. Horszczaruk, HM. Jonkers, A Kwiecien, J. Mosa, A. Peled, AS. Pereira, D. Snoeck, M. Stefanidou, T. Stryszewska, B. Zajac, External treatments for the preventive repair of existing constructions: A review. Constr Build Mater (2018) 193: 435-452. https://doi.org/10.1016/j.conbuildmat.2018.10.173

[30] R. Hendrickx, Using the Karsten tube to estimate water transport parameters of porous building materials. Mater Struct (2013) 46 (8): 1309-1320. https://doi.org/10.1617/s11527-012-9975-2

[31] R. Davies, O. Teall, M. Pilegis, A. Kanellopoulos, T. Sharma, A. Jefferson, D. Gardner, A. Al-Tabbaa, K. Paine, R. Lark, Large scale application of self-healing concrete: design, construction, and testing. Front Mater (2018) 5(51): 1-12. https://doi.org/10.3389/fmats.2018.00051

[32] O. Teall, R. Davies, M. Pilegis, A. Kanellopoulos, T. Sharma, K. Paine, A. Jefferson, R. Lark, D. Gardner, A. Al-Tabbaa, Self-healing concrete full-scale site trials. Proc of the 11th fib International PhD Symposium in Civil Engineering, The University of Tokyo, Japan (2016) 639-646. 